\title{
Exploration and Analysis of the Educational Path of Financial Quotient for College Students Based on Thinking Development
}

\author{
Ning Lang ${ }^{1, *}$ \\ ${ }^{l}$ School of Foreign Languages, Shandong Technology and Business University, Yantai, Shandong 264000, \\ China \\ *Corresponding author. Email:603187950@qq.com
}

\begin{abstract}
Financial quotient is a kind of thinking as well as a kind of management ability. In the context of high-quality development in the current new era, people are increasingly aware of the importance and necessity of financial quotient and financial quotient education. However, due to the lack of financial quotient education in families, schools, and society, today's college students lack financial knowledge, systematic financial quotient knowledge and scientific financial quotient concepts. Phenomena of no desire and inability to improve financial quotient can be found everywhere. Starting from money education and emphasizing the value of intangible assets, schools, families and individuals should focus on the thinking development of a healthy outlook on wealth, continuous learning ability, and a scientific vision of overall situation and holistic view, so as to lay a solid foundation for realizing the value and meaning of life.
\end{abstract}

Keywords: Financial quotient thinking, Educational path, Wealth and value.

\section{INTRODUCTION}

With the rapid development of all walks of life, the rapid growth and transmission of information, and the fierce competition in the market economy, having a high financial quotient is particularly important for anyone. Financial quotient is the wisdom of financial management and the cornerstone of realizing the value and ideal of life. However, the contradiction is that although people's consumption and financial needs are increasing day by day, most people have weak financial abilities and lack of financial knowledge reserves. In contrast to previous education, IQ (intelligence quotient) and EQ (emotional quotient) have always been the focus of parents, schools, and society, while financial quotient is generally missing. With the improvement of China's comprehensive national strength, people are increasingly aware of the importance and necessity of financial quotient and financial quotient education, and more and more people pay attention to the systematic study and training of financial quotient.

\footnotetext{
CLC number: G41, Document identification code: A
}

As the builders and successors of socialism, college students bear the arduous historical mission and responsibilities of the times. Carrying out financial quotient education for college students is a requirement for the comprehensive and coordinated development of college students' own quality and an urgent call for the development of the times. Financial quotient education is to enable people to establish a correct attitude towards wealth, understand the laws of wealth movement, and use wealth scientifically and rationally to realize the dream of life, so as to contribute wisdom and strength to the realization of the Chinese dream of the great rejuvenation of the Chinese nation.

\section{THE STATUS QUO OF COLLEGE STUDENTS' FINANCIAL QUOTIENT ABILITY}

Financial quotient is the seed, and money is the fruit. There is an old saying, if you don't manage money, money won't find you. Everyone is familiar with it. Growing up with the Internet, the post-90s and post-00s college students have become more 
and more aware of the importance of wealth to a better life and personal accomplishment. However, due to the lack of financial knowledge and awareness, "There are many problems in the financial management of college students, and their consumption is irrational, failing to form a systematic financial management concept".[1] Therefore, under the increasing desire for consumption, how to manage money and benefit from it is a topic that college students urgently need to learn.

Judging from the financial quotient of college students in the new era, on the one hand, they are unable to improve their financial quotient. In the elementary and middle school period, most of the only savings such as the gift money of students ended up in the pockets of their parents; when students go to college, their parents' pockets are open to them, and students basically have their own separate accounts. Some students' pocket money is given once a month and some are given in full every semester at a time. Therefore, students' consumption autonomy is thus enhanced. However, due to the lack of financial quotient education in families and schools, young college students lack financial quotient knowledge and have a shallow sense of financial quotient education. Most of them don't have the mature ability to manage and use money, and don't know how to use money to scientifically plan their study and life. On the other hand, they have no intention of improving financial quotient. Affected by multiple factors such as society, family, and peers, the consumption level of a considerable number of college students today is inversely proportional to consumer demand. Their consumption outlook is advanced, their consumption demand is strong, and the consumption structure is unreasonable. They pay attention to fashion consumption, brand consumption, and leisure and enjoyment consumption. The comparing phenomenon is serious. They spend money lavishly, blindly and irrationally regardless of the economic level, never realizing the importance of financial management, or even if they do realize the importance of financial management, they don't have enough selfcontrol and determination to plan consumption reasonably.

Financial quotient is not money, but it can create money and ensure that one can be rich. Financial quotient is to ask people to allocate money reasonably, and use limited money to properly and scientifically arrange life, study and social activities. In recent years, university campus loan problems have frequently appeared. The main reason is that some college students have no financial quotient ability, their consumption concepts and consumption structure are unreasonable, they can't use financial quotient thinking to look at and understand problems, and their risk perception ability is weak. Therefore, it is extremely urgent to carry out financial quotient education in universities, which plays an important role in the establishment of rational consumption concept and the formation of scientific outlook on money and life of college students.

\section{THE VALUE DEMAND OF FINANCIAL QUOTIENT EDUCATION}

Financial management is a part of financial quotient, it is the process of having money and capital before planning, and financial quotient is capable of creating and accumulating wealth, whether it has capital or not. Financial quotient is far from a simple matter of money. It involves people's financial literacy and financial thinking. "Generally speaking, the narrow sense of 'financial quotient' means 'financial intelligence quotient', which includes three aspects: wealth concept, financial management behavior, and financial knowledge. In a broad sense, 'financial quotient' refers to a person's ability to create, manage and use wealth in a market economy in accordance with market laws".[2] Wealth doesn't only refer to money, and all valuable things are wealth, including knowledge, time, energy, health and so on. Therefore, the ability of financial quotient not only includes financial knowledge and financial management ability, but also includes the ability to correctly understand wealth and the ability to add the value of wealth, that is, to maximize the income of intangible wealth.

\subsection{Money Education Is Essential}

Money education is the foundation. To carry out financial quotient education, a must is to first establish financial awareness and educate students to understand what money is, where money comes from, how money is spent, and what the true value of money is. Money is a quantitative manifestation of the ability to control the material world. It is a resource of consumption, use, and exchange. It can measure the specific value of tangible things. Money is the guarantee for people's survival and an indispensable medium for people's material and spiritual enjoyment, but all money is earned by 
people through actual intellectual or physical labor. Against the background of the new era, with the development of economy and society, the rise of the Internet, and the transformation of consumption structure, market competition is becoming fiercer. People need to make more efforts to create and manage money. Therefore, money must be spent on meaningful things. Money education is a compulsory course for everyone. Most contemporary college students enjoy the money given by their parents and spend money without any worries. If schools want to change the current situation of lack of financial awareness and knowledge of financial quotient of college students, it is necessary to carry out financial quotient education among college students. First, they must start with professional financial knowledge and skills, including accounting knowledge, financial knowledge, legal knowledge and its wide-caliber professional basic knowledge, and use the first classroom curriculum, second classroom social practice, cultural and sports activities and other media to enable students to fully understand the knowledge and methods of financial quotient, and master the actual operating skills and methods. Second, it is necessary to give full play to the role of labor education and use excellent traditional cultural resources to stimulate students' striving spirit, educate students to obtain money and create money through personal labor, treat money correctly, and fully understand the glory of labor and the hard-won money, so as to establish a correct view of money. Third, it is necessary to design some financial planning cultural and sports activities, and provide students with social practices such as financial management and investment strategies, so as to exercise students' ability to plan and use money.

\subsection{Paying Attention to the Wealth Value of Intangible Assets}

Financial education is not just equivalent to money education. The most important thing of it is happiness education and personality education, which cultivate students' ability to deal with intangible wealth. Tangible assets such as money and savings are a kind of material existence, and it is easy to measure and define them. The accumulation of all money assets requires health, time, personal connections, knowledge and other intangible wealth to assist and foreshadowing. Intangible assets are neither replaceable nor reversible. The process of properly handling the relationship between tangible and intangible assets and thus creating, managing and controlling wealth can truly reflect a person's comprehensive qualities such as IQ, EQ, financial quotient, and adversity quotient.

The stage of higher education is a critical period for young students to shape their character and increase their abilities, and is a key link in the formation of a correct world outlook, outlook on life, and value. College students focus on personal enjoyment and overemphasize the relationship between money and happiness. This runs counter to the core socialist values and contradicts the goal of college students' growth and success. "In the process of transforming from a college student with a single consumption ability to a social person with the ability to consume and invest, college students face new challenges in work, life, consumption, and investment one after another".[3] Carrying out financial quotient education is to guide students to pay attention to the wealth that these intangible assets such as health, time, and knowledge can create, be good at considering the situation, know how to increase their own value by increasing their intangible assets, be good at using intangible assets to increase their own value, plan life reasonably, formulate life plans and determine life ideals, begin with the end in mind, strengthen the management of time, pay attention to the reporting of learning and education, and refine and embody the vision and expectation of the future in the hard work in universities, so as to realize the value of life.

\section{CULTIVATION OF FINANCIAL QUOTIENT THINKING OF COLLEGE STUDENTS}

The essence of financial quotient education is the cultivation of a way of thinking. The first thing to do to develop financial quotient education is to cultivate students' financial quotient thinking. "Behavioral economics tells us that if we want to understand the choices people actually make in economic activities, we must analyze human motivations in more details".[4] Financial quotient thinking is to use practical skills and methods to change the cognition of society, oneself, and wealth, and to examine problems in a scientific, systematic and comprehensive way, so as to make better choices and judgments in the face of everything. 


\subsection{Establishing a Healthy Outlook on Wealth}

A healthy outlook on wealth is a kind of longterm financial management thinking, which is to do things that meet your status and age according to your actual income, money, knowledge, health and other resources, that is, living within your incomes. At present, with the rise of consumer Internet financial platforms, more and more students are living an "exquisitely poor" life. Ant Credit Pay has become a must-have for their lives, and campus loans and online loans are also increasing. And more and more students earn extra income through part-time jobs, and as a result, part-time jobs have become a rigid demand for them. Therefore, it is really urgent to educate college students to arm themselves with scientific financial thinking and avoid falling into the misunderstandings of life.

To establish a healthy outlook on wealth, college students must first keep their identity in mind, control their desires for consumption, optimize the consumption structure, distinguish between "wants" and "needs", and learn to sort their needs. In today's society, human desires are endless, but the resources needed to satisfy their desires are limited. As the saying goes, it's necessary to make every penny count, which means that you must prioritize consumption and avoid excessive consumption and heavy debt. Secondly, college students must understand the concept of cost, learn to make choices, and weigh gains and losses. According to the definition of economic law, if you want to have more good things, you must give up some other good things. For example, student A uses all the money to buy bags, cosmetics, etc., while student B enrolls in a tutoring class and uses the money to improve personal professional skills. Then according to the principle of cost efficiency, although student B has increased human capital in monetary cost, he or she contains a stock of knowledge, skills and health qualities, so that his or her future expected benefits can be maximized, however, if student A doesn't plan the use of money, it is very likely for him to fall into a state of being kidnapped by consumption.

\subsection{Maintaining Continuous and Upward Learning Ability}

Continuous and upward learning ability is the open-sourcing and realization of personal value, that is, the process of own wealth appreciation, including the appreciation of tangible assets and intangible assets. It is an important way to master wealth and improve the ability to earn wealth, and it is a weapon for personal value to win and compete. To maintain continuous and upward learning ability and realize the growth of personal wealth, first, one must analyze his or her own situation comprehensively and systematically. College students don't have economic savings, and their greatest wealth is knowledge, time, and energy. Therefore, young students must be clear about and highlight their core competitive advantages and existing disadvantages, further identify their direction, make up for shortcomings, maximize advantages, focus on core literacy, and improve overall quality. Second, they must learn how to deal with money, and carry out part-time social work and social practice within the reach and on the premise that they have spare energy after learning. They need to understand the meaning of savings, and learn how to plan and how to allocate the use of money. Third, they must learn to use the thinking of the rich to guide learning, enrich the mind to enrich the pockets, enrich the mind to enrich life, and learn to enjoy the process of making money and saving it not the process of enjoying consumption; it is necessary for them to treat learning as a long-term investment, truly realize the important power of knowledge for gathering wealth, and not to be complacent or stand still because of temporary achievements; they also need to be good at accumulating and using every little bit of material and spiritual wealth to lay the foundation for future development and progress.

\subsection{Cultivating the Overall View and Holistic View}

Money needs to be used in a planned way, so it is life. From financial management to life management, it is a qualitative leap in the path of personal development. Cultivating the overall view and holistic view of college students' financial quotient thinking requires efforts from three aspects including school education, family education, and personal education to build an all-round and fullprocess collaborative education mechanism of party and government leaders, class teachers, counselors, and parents. At present, the path of financial quotient education in universities is not yet mature. School financial quotient education is mostly based on cultural and sports activities, school-based courses are lacking, practical applications are immature, and family financial quotient education is not in place. In addition, the advanced consumption of college students has the 
characteristics of "departing from the Marxist consumption concept and weakening the college students' sense of identity with the mainstream Chinese ideology".[5] Therefore, schools must work hard to teach knowledge and values, and parents must work hard on habit formation, supervision and guidance. The most important thing is that students should actively construct personal financial quotient improvement and development paths. In this process, special attention should be paid to avoiding two extremes: one is to find opportunities to earn money unlimitedly in order to make money, and the other is to avoid being in a pickle to save money in terms of basic living security and learning conditions, "Financial quotient is the basic quality that modern people should derserve,Good at financial management is the conservation of social resources and the optimization of resource allocation, which itself meets the requirements of the Scientific Outlook on Development".[6] The overall view and holistic view of financial quotient education is to establish personal wealth goals from the perspective of life value and national social contribution. Driven by the joint efforts of schools, families, and individuals, it is to formulate feasible and operable academic plans, career plans, and life plans, seek resources to realize goals, and maximize personal value and social benefits.

\section{CONCLUSION}

The ancients said: "圣人不治已病治未病，不治已乱 治未乱 (The saint doesn't treat an illness but prevent from it before he is sick)". "Better late than never" is never the fundamental way to solve the problem. The most important thing that people should do is to set up a correct outlook on life and world, start with scientific, regular and normative wealth management methods, guarantee financial choice with high financial quotient, form judgment and develop scientific good financial habits. At the same time, financial quotient is to manage life, it is to make plans for life, and it is the process of selfmanagement in order to achieve goals and ideals. Cultivating financial quotient is not only to enjoy the wealth brought by financial management knowledge, but more importantly, to enjoy the freedom and choice that wealth brings to life.

All in all, financial quotient is an indicator of how much money is earned, how much money is kept, and how long the money is allowed to work for people. No matter one's academic performance is good or bad, one's family conditions are good or bad, and one's face score is superior or not, no matter one's in good or bad times, youth is the greatest wealth of college students. College students should face up to their wealth, invest in themselves, and lay a solid foundation for realizing the value and meaning of life.

\section{AUTHORS' CONTRIBUTIONS} Lang.

This paper is independently completed by Ning

\section{REFERENCES}

[1] Xiong Hui. Research on the Countermeasures of Positive Financial and Business Behavior of College Students under the Perspective of Financial and Business Education [J]. Jiangsu Commercial Forum, 2021(3).137-139.

[2] Liu Xiangfeng. The Primary Study of Financial Intelligence Education $[\mathrm{J}]$. Journal of Shandong Technology and Business University, 2021(2): 7-13.

[3] Lu Yuan. On the Necessity of Finance Quotient Education in the Quality Training of College Students [J]. Journal of Inner Mongolia Normal University, 2014(9): 59-60.

[4] Robert Frank. The Economic Naturalist: In Search of Explanations for Everyday Enigmas [M]. Beijing Union Press, 2018.

[5] Zhao Yaqi. The Influence of Deficit Spending on College Students Based on the Network Platform [J]. Journal of Jiaozuo University, 2021(3):99-102.

[6] Sheng Derong1. HeHuazheng2 On the Importance of Financial Quotient Education on College Students. [J] Journal of ChengDu University of Technology(Social Sciences), 2012(5):113-116. 